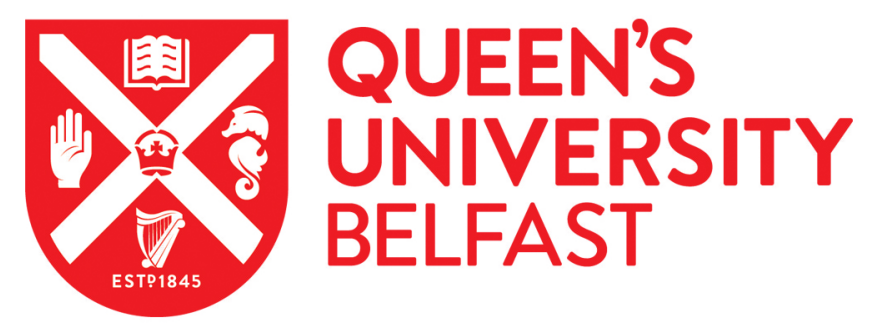

\title{
The Barriers and Facilitators to the Implementation of Interventions for Children with Visual Impairments, Their Parents/Guardians or Educators: A Systematic Scoping Review
}

Yesilkaya, E., Best, P., Byrne, B., \& Marshall, G. (2019). The Barriers and Facilitators to the Implementation of Interventions for Children with Visual Impairments, Their Parents/Guardians or Educators: A Systematic Scoping Review. Child Care in Practice. https://doi.org/10.1080/13575279.2019.1664988

Published in:

Child Care in Practice

Document Version:

Peer reviewed version

Queen's University Belfast - Research Portal:

Link to publication record in Queen's University Belfast Research Portal

Publisher rights

(c) 2019 The Child Care in Practice Group.

This work is made available online in accordance with the publisher's policies. Please refer to any applicable terms of use of the publisher.

\section{General rights}

Copyright for the publications made accessible via the Queen's University Belfast Research Portal is retained by the author(s) and / or other copyright owners and it is a condition of accessing these publications that users recognise and abide by the legal requirements associated with these rights.

\section{Take down policy}

The Research Portal is Queen's institutional repository that provides access to Queen's research output. Every effort has been made to ensure that content in the Research Portal does not infringe any person's rights, or applicable UK laws. If you discover content in the

Research Portal that you believe breaches copyright or violates any law, please contact openaccess@qub.ac.uk. 
1 The barriers and facilitators to the implementation of interventions for

2 children with visual impairments, their parents/guardians or educators:

3 A systematic scoping review

4

5 Word count: 4,947

6

7 ABSTRACT

8

9 A body of research indicates the importance of interventions for promoting the

10 development and progress of children with visual impairments. However, the research

11 available on suitable interventions for this population is relatively sparse. The purpose of

12 this review is to identify, collate and appraise the available research evidence on

13 implementation barriers and facilitators of interventions for children with visual

14 impairments, their parents/guardians or educators.

15 A systematic scoping search of peer-reviewed literature (including grey literature)

16 was conducted from 15 June 2016 to 7 August 2016 and 2 May 2019 to 5 May 2019. Initial

17 searches identified 6,802 papers with 15 meeting the inclusion criteria. Three additional

18 articles were identified through hand searching giving a final total of 18 included studies.

19 The methodological quality score of the studies was variable with $61 \%$ scored in the

20 average quality range. Sensory strategies, a family centred approach, in-service training

21 and routines-based activities were identified as implementation facilitators. Barriers were

22 a lack of adaptive equipment and training for parents and professionals, complicating

23 factors associated with the child's disability and an absence of specialists in interventions. 
Effective intervention strategies differ for this targeted population which requires

25 individualised applications associated with teacher and parent/guardian training. For health

26 or education professionals who work with children with visual impairments, the outcomes

27 of this review suggest that a detailed assessment and identification of the individualised

28 needs of children and their families, coupled with carefully designed and tested support

29 practices to meet their individualised needs as well as promoting integrated working

30 between health and care services, can optimise the positive implications for future practice.

31 Along with this, future consideration should be given to the identification of the needs of

32 children with visual impairments and additional disabilities in order to facilitate the

33 adjustment of intervention strategies for this group.

\section{KEYWORDS}

35 Children, intervention, carers, practice, visual impairment

\section{Introduction}

37 The World Health Organization (WHO) estimates that approximately 19 million children

38 (aged between 0 and 14) worldwide have visual impairments, and 14 million of these

39 children are blind (WHO, 2012a, 2017). Childhood blindness comprises a relatively small

40 percentage (4\%) within global causes of blindness (WHO, 2017). However, the conditions

41 which cause visual impairments in childhood are highly varied, and the conditions can be

42 associated with additional disabilities which require multidisciplinary support strategies

43 for affected children (Rahi, 2005). As such, a range of services are required to support this

44 population and their families as early as possible after diagnosis in order to prevent 45 developmental risks (Campbell, 2007; Fraiberg, 1977; van den Broek et al., 2017; Webster 
$46 \&$ Roe, 1998). Yet the research evidence regarding the most effective and beneficial

47 approaches in this area is scarce.

As the uniqueness and complexity of a child's conditions makes it difficult to

49 accurately address the needs of children, most often interventions take place to provide a

50 multidisciplinary assessment and support for this population. However, previously

51 conducted reviews on interventions for children with visual impairments (children (VI))

52 report that the research evidence is still limited to a generalised intervention model for this

53 population. This is because existing studies have been carried out with a heterogeneous

54 sample and small sample size which makes it difficult to identify a single intervention

55 model for this population (Pérez-Pereira \& Conti-Ramsden, 1999; van den Broek et al., 56 2017).

\section{Interventions for children with visual impairments}

58 Support for children (VI) and their families can be provided through interventions in the 59 child's life at multiple stages. Most often support at an early age is provided through early 60 intervention services by considering the critical period of early life development (Celeste

61 \& Kobal Grum, 2010; Chen, 2014; Fraiberg, 1977; Hatfield \& McCutchen, 2008;

62 McLinden \& McCall, 2016; Pérez-Pereira \& Conti-Ramsden, 1999; van den Broek et al., 63 2017).

64 Early intervention services have a comprehensive structure to minimize 65 developmental delay through systematic practices and family support is an integral part of 66 these services (Celeste \& Kobal Grum, 2010; Ely, Gullifor, \& Hollinshead, 2017; Kobal 67 Grum \& Kobal, 2010; Ross, 2017; Wiley, Parnell, \& Belhorn, 2016). Early intervention 68 for children (VI) aims to optimize residual light perception and promote development, 
69 growth and independent living, as well as provide support for families and minimize the

70 cumulative effects of additional disabilities (Allen, 2011; Brambring, Rauh, \& Beelmann,

71 1996; Chen, 2014; Fazzi, Signorini, Bova, Ondei, \& Bianchi, 2005). Early intervention and

72 support strategies additionally promote access to education and healthcare services (Allen,

73 2011; Brambring et al., 1996; Chen, 2014).

74 For children (VI), accessing education is as important as access to health care 75 services in terms of promoting lifelong learning and progress. However, children (VI) and 76 their families still face difficulties in getting access to education services and the delivery 77 of essential learning materials (WHO, 2012b). Specifically, school age interventions aim 78 to reduce these potential risks relating to access to education. School interventions provide 79 multi-layered support in different skill areas such as communication and socio-emotional 80 skills, fine motor and gross motor skills, cognitive skills and orientation and mobility 81 (Chen, 2014; Stearns, 2017). The implementation of interventions can differ in order to 82 meet the individualised needs of children by personalising the teaching methods (Chen, 83 2014; Wiley et al., 2016). Interventions for school-age children can involve specialists, and health and 85 education services, by incorporating schools to increase the effectiveness of interventions 86 (Chen, 2014; Stearns, 2017). Along with this, if qualified professionals (such as qualified 87 teachers of children with visual impairments (QTVI) or orientation and mobility 88 specialists) are involved in interventions, they can provide an additional contribution and 89 provide further assistance for children and school personnel (Bruce, Ferrell, \& Luckner, 90 2016; Opie, 2018). The comprehensive structure of school interventions can promote 91 access to information, modification of the learning environment, or adaptation of materials 
92 alongside a core curriculum (Brambring et al., 1996; Chen, 2014; Fazzi et al., 2005).

93 Therefore, the consideration of different variables in implementing interventions, such as

94 types of primary diagnosis, coexisting disabilities and the nature and degree of vision, can

95 help to utilise adaptive support strategies (Correa-Torres \& Bowen, 2016; Lewis \& Collis, 96 1997; van den Broek et al., 2017).

97 Despite the evidence on the effectiveness of interventions for children (VI), we still 98 know very little about the barriers and facilitators to the implementation of existing 99 interventions (Brambring et al., 1996; Chen, 2014). This, in itself, is a barrier to optimising 100 the learning and development opportunities for children (VI). Based on the gaps identified, 101 the aim of this review is to synthesise the existing evidence on the components of 102 interventions designed for children (VI), their parents/guardians or educators. To achieve 103 this aim, this synthesis will address issues relating to the barriers and the facilitators of the 104 design and implementation process for interventions for children (VI), their 105 parents/guardians or educators. This review has two main objectives.

106

107 1. To identify the main barriers and facilitators of positive outcomes in existing 108 evidence.

109 2. To identify the potentially beneficial components of existing interventions 110 designed to support children with visual impairments, their parents/guardians or 111 educators. 


\section{Methods}

114 This scoping review was based upon a framework for conducting scoping reviews (Arksey

115 \& O’Malley, 2005). Scoping reviews are beneficial for mapping the key concepts of an

116 area which is complex or has not been researched extensively in the literature. This review

117 includes five key steps (1) identifying the research objectives (2) identifying the relevant

118 studies (3) study selection (4) charting the data and collating and (5) summarising and

119 reporting the results (Arksey \& O’Malley, 2005, p. 9). In this review, primary searching

120 and quality appraisal was conducted by one reviewer (EY) with a sample (20\%) taken and

121 verified by a second reviewer (PB). After determining which papers to include in the

122 review, the data was synthesised and components of the interventions and the research

123 methods of the studies were identified (Arksey \& O’Malley, 2005). All information was

124 charted in a word document including the authors, the date published, country, the research

125 setting, the participants' information, methods, the components of the interventions,

126 outcomes, limitations and the knowledge gaps determined by the authors. After charting

127 was completed, the information was interpreted. Later a summary table was developed 128 (Table 1).

130 Table 1. Characteristics of the included research studies

131 (Preferred location for the Table 1)

133 Systematic search

134 A comprehensive research strategy was conducted using the following databases:

135 Ebscohost, Eric, Science Direct, ProQuest Education, Taylor \& Francis Online, BEI, Zetoc, 
137 sources. ProQuest Dissertations \& Theses: UK \& Ireland, Conference proceedings, Google

138 scholar, Open Grey, Theses Canada Portal, PSYC articles, and RNIB were used for grey

139 literature. A hand search was applied to the reference list of full text articles.

\section{Inclusion Criteria}

142 (1) Types of participants: Included children (VI) who might have additional 143 disabilities based on the International Classification of Diseases and Related Health 144 problems, $10^{\text {th }}$ edition WHO (2010) criteria. Their parents/guardians, educators or 145 other service providers also took part in some studies. Studies included children 146 aged 0 to 14 years old because support in a child's early years and in the early 147 school years are important in future learning and development (Gorey, 2001; King, $148 \quad 2014)$.

149 (2) Types of studies: Intervention based implementations for children (VI), 150 parents/guardians or education professionals were included. Qualitative, 151 quantitative and mixed method studies were selected.

152 (3) Language: Only articles in English were searched because of a language 153 restriction. Studies written in other languages were excluded.

154 (4) Time period: Studies between 1980 and 2019 were reviewed. Research studies out 155 of this time period were excluded. 1980 was selected as a start date because some 156 distinctive ideas (e.g., inclusion and statementing) started to appear in the field of 157 special education at that time and these ideas led to changes in practical 

2013) can be seen in Table 2.

161 Table 2. Search terms

\section{2 (Preferred location for the Table 2)}

\section{Quality appraisal}

165 The Mixed Method Appraisal Tool (MMAT) version 2011 (Pluye et al., 2011) was used to 166 appraise the methodological quality of the studies. The MMAT tool was selected because

167 the research designs of the studies vary. This tool includes clearly divided sub-sections for 168 qualitative, quantitative and mixed method research designs. Each sub-section includes

169 questions to appraise a selected study. The overall quality score for each study can be 170 reached by assessing different criteria about the research questions, analysis process, 171 recruitment of participants, sampling strategy or complete outcome data. There are four 172 items for qualitative, quantitative (randomised trials, quantitative non-randomised trials 173 and quantitative descriptive) studies; and three items for mix method studies. These criteria 174 can be answered in 'Yes, No or Can't tell'. For each of the answers descriptors $(*, * *, * * *$ 175 or $* * * *)$ can be used to represent the score. For example $(*)$ descriptor means that one 176 criterion was met, and $(* * * *)$ descriptor means that all criteria were met. The total score is

177 divided into four to obtain a score for each article. The validity and reliability of the pilot 178 appraisal tool was inspected by the developers (Pluye et al., 2011). 
181 As outlined in Figure 1, 6,802 papers were identified through the systematic scoping 182 review. After screening the identified publications and removing duplications, 437 papers 183 remained. From 437 papers, 18 studies from seven different countries (Germany $(\mathrm{n}=1)$, 184 Italy $(n=1)$, Netherlands $(n=1)$, Turkey $(n=1)$, USA $(n=11), \operatorname{UK}(n=1)$, Iran $(n=1)$, and one 185 non-specified) were included by taking the inclusion criteria into consideration (Figure1). 186 The sample size of the studies varies (Table 1). The age of the sample size is between birth 187 and 14 years old. The total sample size of the studies includes approximately 4,000 188 children (VI). Half of the reviewed studies ( $\mathrm{n}=9,50 \%)$ include children (VI) and additional 189 disabilities. More than half of the studies (55\%) were conducted between 1990 and 2010.

191 Figure 1. Flow diagram for systematic scoping review

192 (Preferred location for the Figure 1)

193 *Sourced from the PRISMA Group (Moher, Liberati, Tetzlaff, \& Altman, 2009)

\section{Methodological quality}

196 The methodological quality of the 18 studies varied. The lowest score was $25 \%$ and the 197 highest score was 75\%. Overall three studies were considered low and 15 considered 198 average (Table 1). Lower scores were attributed to a lack of appropriate consideration 199 being given to the researcher's reflexivity (qualitative studies) and a lack of information 200 on selection bias or a low response rate/outcome data in quantitative studies. 
203 The existing studies reported some limitations that affected the outcomes of the

204 interventions for children (VI). These limitations were grouped into three categories.

206 1. Lack of training for parents/guardians or professionals and lack of access to the 207 information and services $(\mathrm{n}=6,33.3 \%)$ (Behl, White, \& Escobar, 1993; Dennison, 2001;

208 Dikowski, 1995; Hill, Dodson-Burk, Hill, \& Fox, 1995; Joffee, 1988; Klein, Van Hasselt, 209 Trefelner, Sandstorm, \& Brandt-Snyder, 1988).

210 A lack of training for parents/guardians or professionals and a lack of information about 211 access to services are reported as factors which negatively affect the intervention outcomes.

212 The training needs of professionals were identified as assessments, planning or 213 modifications of the applications and understanding the impacts of visual impairment (Behl 214 et al., 1993; Dikowski, 1995). Additionally, a lack of parental training was identified as an 215 issue that hinders the delivery of appropriate care for children.

217 2. Lack of adaptive equipment ( $\mathrm{n}=4,22 \%)$ (Chen \& Haney, 1999; Dennison, 2001;

218 Dikowski, 1995; Joffee, 1988).

219 Equipment used in an intervention needs to be adapted to suit each participant. Adapted 220 equipment helps to meet the learning or development needs of children (VI). The lack of 221 adaptive equipment used in applications may prevent the effectiveness of intervention 222 outcomes. 
224 3. Complicating factors associated with the child's primary condition (i.e. additional 225 disabilities) (n=4, 22\%) (Chen \& Haney, 1999; Dale et al., 2019; Rowland \& Schweigert, 226 2000; Skellenger \& Hill, 1994) and absence of specialists in interventions ( $n=5,27.77 \%)$ 227 (Behl et al., 1993; Dennison, 2001; Dikowski, 1995; Hill et al., 1995; Klein et al., 1988).

228 Children with additional disabilities and those with complex health needs require additional 229 support tailored according to their needs. However, as the studies highlight, the parents and 230 the professionals faced some challenges while modifying the materials or the learning 231 environments according to the personalised needs of children. Modification and adaptation 232 of the materials or applications require the joint involvement of trained specialists and 233 parents/guardians. Although the involvement of enough specialists in interventions is 234 crucial, the involvement of trained specialists who have knowledge of diagnosis, health 235 care assessment or evaluation is a reported challenge to existing applications (Behl et al., 236 1993; Chen \& Haney, 1999; Rowland \& Schweigert, 2000).

238 Potentially beneficial implementation facilitators of the interventions

239 This review has identified potentially beneficial practices to the implementation of 240 interventions. Potentially beneficial practices reported by the authors of the articles are 241 grouped into four categories: (1) sensory strategies (2) a family-centred approach, (3) in242 service training, (4) routines-based activities. These four categories will be discussed 243 below.

245 1. Sensory strategies: The reviewed studies emphasise the importance of applying visual 246 impairment specific strategies while working with children. Sensory strategies can be 
247 grouped into three broad categories: (a) communication practices, (b) tactile and auditory

248 activities, (c) orientation and mobility.

249 (a) Communication practices

250 Slightly under half of the reviewed studies $(n=7,38.8 \%)$ emphasised that developing

251 communication skills between children and adults can promote daily life functioning

252 because it helps to meet children's expressed needs and wants (Bregani et al., 1981; Bruce,

253 2002; Chen \& Haney, 1999; Janssen et al., 2011; Klein, Van Hasselt, Trefelner, Sandstorm,

254 \& Brandt-Snyder, 1988; Rowland \& Schweigert, 2000; Sarica et al., 2015).

255 Communication practices most often took place within a structured intervention practice.

256 The studies emphasise that personalised, and visual impairment specific practices, are best

257 modified in accordance with the needs of children and their parents/guardians because this

258 improves communication and interaction between parents/guardians and children (Bregani

259 et al., 1981; Bruce, 2002; Chen \& Haney, 1999; Janssen et al., 2011; Klein et al., 1988;

260 Rowland \& Schweigert, 2000; Sarica et al., 2015).

261 (b) Tactile and auditory activities

262 Less than one quarter of the studies $(n=4,22 \%)$ include tactile or auditory cues (i.e. sound

263 making toys, reaching for or grasping sound making objects) (Beelmann \& Brambring,

264 1998; Chen \& Haney, 1999; Erickson et al., 2007; Joffee, 1988). These studies emphasise

265 the benefits of providing adaptive tactile or auditory materials for children. Despite the

266 different implementations, the research results outline that tactile and auditory cues might

267 help children interact with their environment, encourage child independent mobility and

268 increase communication between parents/guardians and children (Joffee, 1988; Chen \&

269 Haney, 1999; Erickson et al., 2007). 
(c) Orientation and mobility

271 Several studies $(n=3,16.6 \%)$ focused on orientation and mobility skills through involving

272 professionals who are experts in orientation and mobility (Beelmann \& Brambring, 1998;

273 Harley, Long, Merbler, Langley, \& Wood, 1986; Joffee, 1988). In these studies, promoting

274 orientation and mobility skills has been linked with the existence of orientation and

275 mobility specialists in intervention.-These studies report that integrating orientation and

276 mobility within interventions with a particular focus on increasing the future mobility of

277 children can be an effective strategy. The activities applied in reviewed studies vary

278 according to the individualised needs of children, including locomotion skills, purposeful

279 navigation, and orientation or mobility.

281 2. A family-centred approach: Within this review, 13 studies (72\%) emphasise the

282 importance of collaboration between parents/guardians and professionals (Beelmann \& 283 Brambring, 1998; Behl et al., 1993; Bregani et al., 1981; Chen \& Haney, 1999; Dale et al., 284 2019; Dennison, 2001; Dikowski, 1995; Erickson et al., 2007; Harley et al., 1986; Janssen 285 et al., 2011; Joffee, 1988; Klein et al., 1988; Sarica et al., 2015). A family-centred approach 286 is an important outcome of these studies which revealed some valuable points.

287 Firstly, these 13studies highlight the role of professional guidance which may 288 provide valuable information about the progress of the child. These studies emphasise that 289 professional guidance had a relevance for promoting parental involvement and family290 professional collaboration. Additionally, giving families some opportunities to discuss 291 their knowledge on the overall development process of their children was a helpful strategy 292 in order to identify the needs of the child and the family. Accordingly, families had specific 
293 knowledge on how their children learned. This kind of information helped professionals to

294 be aware of the child's cues in order to address the needs of the children.

296 3. In-service training: Half of the studies $(n=9,50 \%)$ involve teachers, early 297 interventionists or intervention coaches to improve their competence in supporting children 298 (VI) in the learning environments (Harley, 1986; Joffee, 1988; Skellenger and Hill, 1994;

299 Dikowski, 1995; Chen \& Haney, 1999; Rowland and Schweigert, 2000a; Dennison, 2001;

300 Bruce, 2002; Erickson et al., 2007). Less than half of the studies ( $=8,44 \%)$ emphasise a 301 gap in teacher and early interventionist training and a lack of knowledge by teachers about 302 visual impairment specific issues. Interventions used to address these gaps were in-service 303 training (Bruce, 2002; Chen \& Haney, 1999; Dennison, 2001; Dikowski, 1995; Rowland $304 \&$ Schweigert, 2000a) or visual impairment specific trainings for teachers or early 305 interventionists as a part of interventions (Harley et al., 1986; Joffee, 1988; Skellenger \& 306 Hill, 1994). Reviewed studies $(n=8,44 \%)$ applied in-service training as a way of 307 collaborating with families or other professionals (Bruce, 2002; Deborah Chen \& Haney, 308 1999; Dennison, 2001; Dikowski, 1995; Harley et al., 1986; Joffee, 1988; Rowland \& 309 Schweigert, 2000; Skellenger \& Hill, 1994). The trainings were often reported as beneficial 310 for education professionals or parents/guardians because the trainings increased access to 311 information and maintained collaboration between health or education professionals and 312 parents/guardians.

314 1. Routines-based activities: More half of the studies $(n=11,61 \%)$ conducted an 315 intervention in the home settings of children with the aim of involving 
parents/guardians in interventions (Beelmann \& Brambring, 1998; Behl et al.,

317 1993; Bregani et al., 1981; Chen \& Haney, 1999; Dennison, 2001; Erickson et al., 318 2007; Harley, 1986; Hill et al., 1995; Joffee, 1988; Klein et al., 1988; Sarica et al., 319 2015). Six studies (33\%) implemented routines-based activities (Behl et al., 1993; 320 Bruce, 2002; Chen \& Haney, 1999; Dikowski, 1995; Rowland \& Schweigert, 2000; 321 Sarica et al., 2015). The outcomes of implemented applications indicate that 322 routines-based activities show some positive effects. For example, it can increase parents/guardians-child interaction, parents/guardians can learn to facilitate and adapt activities in their daily routines, or they can learn to identify promoters and hindrances in terms of adapting the environment according to their child's. Additionally, parents/guardians can recognise their child's communication cues which increase the quality of communication between family members and children.

\section{Intervention outcomes}

330 The reviewed studies reported the benefits of the intervention for children (VI),

331 parents/guardians and educators. Potentially beneficial components of the interventions are

332 orientation and mobility activities, professional guidance, home-based practices, in-service

333 training, routine-based activities, family training and communication practices (Table 3).

334 Table 3. The components of the reviewed interventions

335 (Preferred location for the Table 3)

336 Of the reviewed studies, 15 of them (83.3\%) reported benefits of the intervention for their 337 participants in following areas: 
Benefits for children

1. Positive outcomes on skill acquisition (Bregani et al., 1981; Hill et al., 1995; Rowland \& Schweigert, 2000; Skellenger \& Hill, 1994).

2. Communication development (Bruce, 2002; Chen \& Haney, 1999; Janssen et al., 2011).

3. Increased independence (Chen \& Haney, 1999; Rowland \& Schweigert, 2000).

4. Enhanced orientation and mobility performance (Beelmann \& Brambring, 1998; Harley et al., 1986).

5. Development of fine and gross motor skills (Beelmann \& Brambring, 1998).

6. Enhanced parents/guardian-child interaction (Bregani et al., 1981; Janssen et al., 2011; Sarica et al., 2015).

Benefits for parents/guardians are reported as

2. Increased knowledge about visual impairments (Dikowski, 1995).

3. Increased knowledge on how to support and communicate with children more effectively (Chen \& Haney, 1999; Dikowski, 1995; Sarica et al., 2015).

4. Increased knowledge on how to respond to the child's cues (Chen \& Haney, 1999; Sarica et al., 2015).

5. Reduced parental stress (Dale et al., 2019; Khooshab, Jahanbin, Ghadakpour, \& Keshavarzi, 2016).

Benefits for teachers are reported as:

1. Increased knowledge on how to assist children (Hill et al., 1995) 
360 Null effects of the interventions are also reported by the authors. Of the reviewed studies

361 eight of them (44.4\%) report null, partially null and negative effects of the interventions or

362 activities for their participants (Beelmann \& Brambring, 1998; Behl, White, \& Escobar,

363 1993; Chen \& Haney, 1999; Dale et al., 2019; Harley et al., 1986; Janssen et al., 2011;

364 Rowland \& Schweigert, 2000; Skellenger \& Hill, 1994).

\section{Discussion}

366 This scoping review sought to explore the barriers and facilitators of interventions carried 367 out with children (VI), their parents/guardians or educators. This study is important in 368 contributing knowledge by identifying the potentially beneficial components of existing 369 interventions for this targeted group through systematic scoping methodology. The robust 370 nature of the systematic review and quality assessment help to specify different 371 components of the interventions. As identified, there is a scarcity of systematic scoping 372 reviews in this targeted area.

373 The evidence from 18 reviewed studies indicates that the effectiveness of 374 interventions for children (VI) requires a comprehensive approach in terms of adapting the 375 environment and involving parents/guardians in the implementation process. Although 376 implementation of different practices has been reported in 18 studies, some common 377 barriers to and facilitators of approaches have emerged which can be seen below.

379 Key barriers to the approaches

380 A lack of knowledge about visual impairment, the complicating features of a child's 381 disability and the challenges parents/guardians face in accessing information are identified 382 as barriers to the implementation of successful interventions. Similar issues are highlighted 
383 in other studies where the subjects are children (VI) (Gal, Dyck, \& Passmore, 2010; 384 Kappen, 2017; Probst \& Borders, 2017; Stearns, 2017; van den Broek, Janssen, van 385 Ramshorst, \& Deen, 2006). Within this review, half of the studies involve children (VI) 386 and additional disabilities. However, few studies gave details regarding the needs of those 387 with other disabilities in addition to visual impairment. This knowledge gap is addressed 388 in other studies by considering the increasing number of this subgroup (Argyropoulos \& 389 Thymakis, 2014; Jones \& Hensley-Maloney, 2015; McLinden \& McCall, 2016; Salt \& 390 Sargent, 2014). As these publications highlight, the care and support techniques are diverse 391 and the identification of the unique needs of this subgroup may require further research.

392 This review shows that the professionals' role seems important in influencing the 393 barriers experienced by children (VI) with or without additional disabilities. Therefore, the 394 absence of specialists in interventions is revealed as a barrier in optimising positive 395 research outcomes. The key challenges of scheduling an intervention are service 396 coordination, organisation of the programmes and scheduling and involving certificated 397 trainers (Beelmann \& Brambring, 1998; Behl et al., 1993; Dikowski, 1995; Hill et al., 1995; 398 Joffee, 1988; Sarica et al., 2015). Similarly, the results of the recent studies highlight the 399 families' concerns regarding a lack of professional support and access to the services 400 (Barbieri et al., 2016; Ben-David \& Nel, 2013; Geldenhuys \& Wevers, 2013; Lupón, 401 Armayones, \& Cardona, 2018). However, fewer studies indicate that the satisfaction or 402 dissatisfaction of the families regarding the services varied regarding differences in needs, 403 economic well-being or parental knowledge on services (Pickard \& Ingersoll, 2016; 404 Robert, Leblanc, \& Boyer, 2015). In several studies, the importance of individualised 405 support to meet the needs of children (VI) is emphasised (Lang, Hintermair, \& Sarimski, 
406 2017; Lupón et al., 2018; Oulton, Sell, Kerry, \& Gibson, 2015; Roe, 2008). A difficulty

407 identified in implementing individualised practices for each child is the requirement for a

408 carefully designed and well-organised long-term application. This issue may require a

409 combination of different support strategies while studying with children (VI) and who has

410 additional disabilities (Aitken, 2000; McLinden \& McCall, 2016; Solebo \& Rahi, 2014).

411 Overall, the evidence provides valuable information in understanding what kind of

412 intervention strategies were applied and what kind of strategies have worked.

\section{$413 \quad$ Key facilitators of the approaches}

414 The outcomes of this review show that a detailed and ongoing assessment of the

415 intervention process is necessary for increasing potential benefits (Bregani et al., 1981;

416 Dennison, 2001; Erickson et al., 2007; Hill et al., 1995; Rowland \& Schweigert, 2000). It

417 is emphasised that home visits, adaptive equipment and vision specific training for

418 parents/guardians and professionals have the potential to optimise the benefits of the

419 intervention outcomes. Similarly, the literature indicates the possible benefits of home

420 visits on building relationships between participants and providers, monitoring progress

421 and exploring participant experiences (Avellar et al., 2014; Paton, Grant, \& Tsourtos,

422 2013). However, it has been suggested that more research is needed to understand the

423 effects of home visits on research outcomes (Avellar et al., 2014; Paton et al., 2013;

424 Peacock, Konrad, Watson, Nickel, \& Muhajarine, 2013). Additionally, Peacock et al.

425 (2013) argue that interventions which include home visits should be tailored to meet the

426 participants' needs to prevent unintended outcomes. Similar to the results of this review,

427 training needs of parents or professionals is emphasised in the literature in order to develop 
428 appropriate and effective skills to support children (VI) (Ben-David \& Nel, 2013;

429 Geldenhuys \& Wevers, 2013).

430 The potentially beneficial practices of existing applications for children (VI) were mapped

431 into four stages (Figure 2). These are: (1) a detailed assessment of participants' needs, (2)

432 the family-centred approach for promoting implementations of interventions, (3) feedback

433 and suggestions provided by the participants, (4) revisiting the techniques and strategies

434 after receiving participants' feedback.

436 Figure 2. Mapping the outcomes of the studies: Potentially beneficial components of the

437 interventions for children with visual impairments

438 (Preferred location for the Figure 2)

$440 \quad$ Strengths and limitations

441 This robust and comprehensive search has been conducted to identify the key components

442 of existing interventions for children (VI), their families or education professionals.

443 Additionally, the barriers to or facilitators of the strategies that have been addressed in the

444 reviewed research studies were identified.

445 Although a systematic methodological framework is followed through the 446 reviewing process, there are still some limitations. Firstly, a single reviewer interpreted the 447 data and mapped the results which can result in reviewer selection bias. A relatively small 448 number of studies were identified regarding the selection criteria of this review. No meta449 analysis was conducted due to heterogeneity within the sample. Secondly, the 450 methodological procedure of this review is based upon the framework of Arksey and 
451 O'Malley (2005) and it does not reflect any other alternative approaches to the scoping

452 review. Thirdly, as an inclusion criterion, all studies reviewed were only in English which

453 is a language bias. As a result of this criterion some intervention studies that have been

454 conducted with targeted populations published in languages other than English were

455 excluded. This might limit the outcomes of this review.

456 To our knowledge, from the results of this review it is difficult to separate the

457 impact of additional disabilities on the implementation of interventions for this population,

458 and this situation should inform the identified strategies in future research. Limitations of

459 the theoretical robustness of the articles identified a need for future research to put the

460 emphasis on the broader implementation of interventions through a comprehensive

461 theoretical framework.

\section{Future research}

464 The review results indicate that although a variety of practices are available, there is still a

465 lack of information on the process of design and implementation of effective interventions.

466 A lack of research evidence on details of the applications is evident on the implementation

467 of strategies for children in primary school settings. This issue covers the determination of

468 teachers' needs in order to understand how educators possibly meet the needs of pupils

469 with visual impairments and those with additional disabilities. Identifying these topics

470 through a robust theoretical framework would make the issues clear as a few studies report

471 that limitations in the intervention process may have occurred because of a lack of needs

472 assessment and poor design (Harley et al., 1986; Joffee, 1988; Rowland \& Schweigert,

473 2000). Overall, the scarcity of studies in the targeted research area, the complex nature of 
474 interventions for children (VI), and the limited information provided about the design of

475 interventions in identified studies were the main issues that appeared during the review

476 process. It is expected that the detailed outcomes of this study will provide some ideas for

477 future researchers and practitioners by considering the different components of the

478 interventions for children (VI), their parents/guardians and educators before designing such

479 interventions.

480

\section{Conclusion}

482 This review on interventions for children (VI), their families and education professionals 483 identified some implementation barriers and facilitators to existing strategies. The 484 identified implementation facilitators were sensory strategies, a family-centred approach, 485 in-service training and routines-based activities. These facilitators were reported as factors 486 which may optimise the positive outcomes of the practices, particularly in the development 487 and progress of children (VI). These factors can also increase parental involvement in 488 interventions. The identified barriers were a lack of adaptive equipment, training for 489 parents/guardians and professionals, complicating factors associated with a child's 490 disability and an absence of specialists in interventions. As far as could be identified in this 491 review, the diversity of this population and the scarcity of research on this group resulted 492 in a lack of research evidence. This makes it difficult to identify effective strategies within 493 interventions for different age groups of children (VI). The results of this review highlight 494 the importance of a personalised needs assessment before carrying out an intervention. 495 Additionally, the involvement of carefully designed and tested strategies in interventions 496 can optimise positive outcomes for future practices carried out by health and care or 
education services. In addition, it emerged that the identification of the needs of children

498 (VI) and additional disabilities should be considered in order to develop effective support

499 strategies for this group.

\section{References}

Aitken, S. (2000). Teaching children who are deafblind: Contact, communication and learning. London: David Fulton.

Allen, G. (2011). Early intervention: Smart investment, massive savings the second independent report to Her Majesty's Goverment. In Independent Review.

Argyropoulos, V., \& Thymakis, P. (2014). Multiple disabilities and visual impairment: An action research project. Journal of Visual Impairment \& Blindness, 108(2), 163167. https://doi.org/10.1111/j.1467-9639.1991.tb00167.x

Arksey, H., \& O’Malley, L. (2005). Scoping studies: Towards a methodological framework. International Journal of Social Research Methodology, 8(1), 19-32. https://doi.org/10.1080/1364557032000119616

Avellar, S., Paulsell, D., Sama-Miller, E., Del Grosso, P., Akers, L., \& Kleinman, R. (2014). Home visiting evidence of effectiveness review: Executive summary.

Barbieri, M. C., Broekman, G. V. D. Z., Souza, R. O. D. de, Lima, R. A. G. de, Wernet, M., \& Dupas, G. (2016). Rede de suporte da família da criança e adolescente com deficiência visual: Potencialidades e fragilidades. Ciência \& Saúde Coletiva, 21(10), 3213-3223. https://doi.org/10.1590/1413-812320152110.19562016

Beelmann, A., \& Brambring, M. (1998). Implementation and effectiveness of a homebased early intervention program for blind infants and preschoolers. Research in Developmental Disabilities, 19(3), 225-244.

Behl, D., White, K. R., \& Escobar, C. M. (1993). New Orleans early intervention study of children with visual impairments. Early Education and Development, 4(4), 256-274. https://doi.org/10.1207/s15566935eed0404

Ben-David, B., \& Nel, N. (2013). Applying Bronfenbrenner's ecological model to identify the negative influences facing children with physical disabilities in rural areas in Kwa-Zulu Natal. Africa Education Review, 10(3), 410-430. https://doi.org/10.1080/18146627.2013.853538

Brambring, M., Rauh, H., \& Beelmann, A. (1996). Early childhood intervention: Theory, evaluation, and practice (M. Brambring, H. Rauh, \& A. Beelmann, Eds.). Berlin; New York: Walter de Gruyter.

Bregani, P., Ceppelini, C., Cerabolini, R., Contini, O., Damascelli, A., Livingstone, J. B., ... Rocca, A. (1981). Blind children: Prevention of emotional disturbances by early intervention with parents and child. Courrier, 31, 256-262.

Bruce, S. M. (2002). Impact of a communication intervention model on teachers' practice with children who are congenitally deaf-blind. Journal of Visual Impairment \& Blindness, 96(3), 154-168.

Bruce, S. M., Ferrell, K., \& Luckner, J. L. (2016). Guidelines for the administration of 
educational programs for students who are deaf/hard of hearing, visually impaired, or deafblind. Journal of the American Academy of Special Education Professionals, $47,47-59$.

Campbell, J. (2007). Understanding the emotional needs of children who are blind. Journal of Visual Impairment \& Blindness, 101(7), 351-355.

Celeste, M., \& Kobal Grum, D. (2010). Social integration of children with visual impairment: A developmental model. Elementary Education Online Online, 9(1), 11-22. Retrieved from http://ilkogretim-online.org.tr

Chen, Deborah. (2014). Essential elements in early intervention: Visual impairment and multiple disabilities (D. Chen, Ed.). American Foundation for the Blind.

Chen, Deborah, \& Haney, M. (1999). Promoting learning through active interaction. Project PLAI. Final report. Washington.

Correa-Torres, S. M., \& Bowen, S. K. (2016). Recognizing the needs of families of children and youth who are deafblind. American Annals of the Deaf, 4(Fall), 454461.

Dale, N. J., Sakkalou, E., O’Reilly, M. A., Springall, C., Sakki, H., Glew, S., ... Salt, A. T. (2019). Home-based early intervention in infants and young children with visual impairment using the Developmental Journal: longitudinal cohort study. Developmental Medicine \& Child Neurology, 61(6), 697-709. https://doi.org/10.1111/dmcn.14081

Dennison, E. M. (2001). Project VIISA Outreach. Outreach services to assist states to replicate a training model for early interventionists in low insidence disability condition: Blindness and visual impairment. Final report. Logan, Utah.

Dikowski, T. J. (1995). A parent training programme for increasing the visual development of school-aged children. Nova Southeastern University.

Ely, M. S., Gullifor, K., \& Hollinshead, T. (2017). Family-centered early intervention visual impairment services through matrix session planning. Journal of Visual Impairment \& Blindness, 111(2), 169-174.

Erickson, K. A., Hatton, D., Roy, V., Fox, D., \& Renne, D. (2007). Literacy in early intervention for children with visual impairments: Insights from individual cases. Journal of Visual Impairment \& Blindness, 101(2), 1-26. Retrieved from http://eric.ed.gov/?id=EJ755444

Fazzi, E., Signorini, S. G., Bova, S. M., Ondei, P., \& Bianchi, P. E. (2005). Early intervention in visually impaired children. International Congress Series, 1282, 117-121. https://doi.org/10.1016/j.ics.2005.05.200

Fraiberg, S. L. (1977). Insights from the blind: Comparative studies of blind and sighted infants. New York: Basic Books.

Gal, E., Dyck, M. J., \& Passmore, A. (2010). Relationships between stereotyped movements and sensory processing disorders in children with and without developmental or sensory disorders. American Journal of Occupational Therapy, 64(3), 453-461. https://doi.org/10.5014/ajot.2010.09075

Geldenhuys, J. L., \& Wevers, N. E. J. (2013). Ecological aspects influencing the implementation of inclusive education in mainstream primary schools in the Eastern Cape, South Africa. South African Journal of Education, 33(3), 1-18. https://doi.org/10.15700/201503070804

Gorey, K. M. (2001). Early childhood education: A meta-analytic affirmation of the 
short- and long- term benefits of educational opportunity. School Psychology Quarterly, 16(1), 9-30. https://doi.org/10.1521/scpq.16.1.9.19163

Harley, R. K., Long, R. G., Merbler, J. B., Langley, M. B., \& Wood, T. A. (1986). The development of a program in orientation and mobility for multi-handicapped blind infants (Peabody Mobility Kit for infants). Final report. Washington.

Hatfield, N., \& McCutchen, D. (2008). Early intervention guidelines for infants and toddlers with visual impairment in Washington State. Washington.

Hill, M. M., Dodson-Burk, B., Hill, E. W., \& Fox, J. (1995). An infant sonicguide intervention program for a child with a visual disability. Journal of Visual Impairment \& Blindness, 89(4), 329-336.

Janssen, M. J., Riksen-Walraven, J. M., van Dijk, J. P. M., Huisman, M., \& Ruijssenaars, W. A. J. J. M. (2011). Fostering harmonious interactions in a boy with congenital deaf-blindness: A single case study. Journal of Visual Impairment \& Blindness, 105(9), 560-572. Retrieved from http://apps.webofknowledge.com.proxy2.library.mcgill.ca/full_record.do?product= WOS\&search $\_$mode $=$AdvancedSearch\&qid $=9 \& S I D=3 \mathrm{AfCcp} \overline{\mathrm{A}} 4 \mathrm{VdHzWa9gkaT} \& p$ age $=18 \&$ doc $=178 \&$ cacheurlFromRightClick $=$ no

Joffee, E. (1988). A home-based orientation and mobility program for infants and toddlers. Journal of Visual Impairment \& Blindness, 87(7), 282-285.

Jones, B. A., \& Hensley-Maloney, L. (2015). Meeting the needs of students with coexisting visual impairments and learning disabilities. Intervention in School and Clinic, 50(4), 226-233. https://doi.org/10.1177/1053451214546401

Kappen, B. (2017). Keys to educational success: Teaching students with visual impairments and multiple disabilities. Journal of Visual Impairment \& Blindness, 111(1), 88.

Khooshab, E., Jahanbin, I., Ghadakpour, S., \& Keshavarzi, S. (2016). Managing parenting stress through life skills training: A supportive intervention for mothers with visually impaired children. International Journal of Community Based Nursing and Midwifery, 4(3), 265-273. Retrieved from http://www.ncbi.nlm.nih.gov/pubmed/27382593

King, K. (2014). Importance of early childhood education (Ferris State University). Retrieved from http://hdl.handle.net/2323/5688

Klein, B., Van Hasselt, V. B., Trefelner, M., Sandstorm, D. J., \& Brandt-Snyder, P. (1988). The parent and toddler training project for visually impaired and blind multihandicapped children. Journal of Visual Impairment \& Blindness, 82(2), 5964.

Kobal Grum, D., \& Kobal, B. (2010). Early intervention of the blind and visually impaired children and their families: A Slovenian case. Hrvatska Revija Za Rehabilitacijska Istraživanja, 46(2), 116-127.

Lang, M., Hintermair, M., \& Sarimski, K. (2017). Social-emotional competences in very young visually impaired children. British Journal of Visual Impairment, 35(1), 2943. https://doi.org/10.1177/0264619616677171

Lewis, V., \& Collis, G. (1997). Blindness and psychological development in young children (V. Lewis \& G. M. Collis, Eds.). Leicester: The Bristish Psychological Society.

Lupón, M., Armayones, M., \& Cardona, G. (2018). Quality of life among parents of 
664

665

666

667

668

669

670

671

672

673

674

675

children with visual impairment: A literature review. Research in Developmental Disabilities, 83(July 2017), 120-131. https://doi.org/10.1016/j.ridd.2018.08.013

McLinden, M., \& McCall, S. (2016). Learning through touch: Supporting children with visual impairments and additional difficulties. New York: Routledge.

Moher, D., Liberati, A., Tetzlaff, J., \& Altman, D. G. (2009). Preferred reporting items for systematic reviews and meta-analyses: The PRISMA Statement. PLoS Medicine, 6(7), e1000097. https://doi.org/10.1371/journal.pmed.1000097

Opie, J. (2018). Educating students with vision impairment today: Consideration of the expanded core curriculum. British Journal of Visual Impairment, 36(1), 75-89. https://doi.org/10.1177/0264619617730861

Oulton, K., Sell, D., Kerry, S., \& Gibson, F. (2015). Individualizing hospital care for children and young people with learning disabilities: It's the little things that make the difference. Journal of Pediatric Nursing, 30(1), 78-86. https://doi.org/10.1016/j.pedn.2014.10.006

Paton, L., Grant, G., \& Tsourtos, G. (2013). Exploring mothers' perspectives of an intensive home visiting program in Australia: A qualitative study. Contemporary Nurse, 43(2), 191-200. https://doi.org/10.5172/conu.2013.43.2.191

Peacock, S., Konrad, S., Watson, E., Nickel, D., \& Muhajarine, N. (2013). Effectiveness of home visiting programs on child outcomes: A systematic review. BMC Public Health, 13(1), 17. https://doi.org/10.1186/1471-2458-13-17

Pérez-Pereira, M., \& Conti-Ramsden, G. (1999). Language development and social interaction in blind children. Hove: Psychology.

Pickard, K. E., \& Ingersoll, B. R. (2016). Quality versus quantity: The role of socioeconomic status on parent-reported service knowledge, service use, unmet service needs, and barriers to service use. Autism, 20(1), 106-115. https://doi.org/10.1177/1362361315569745

Pluye, P., Robert, E., Cargo, M., Bartlett, G., O'Cathain, A., Griffiths, F., ... Rousseau, M. C. (2011). A mixed methods appraisal tool for systematic mixed studies reviews. Retrieved from http://mixedmethodsappraisaltoolpublic.pbworks.com/w/file/fetch/84371689/MMA T 2011 criteria and tutorial 2011-06-29updated2014.08.21.pdf

Probst, K. M., \& Borders, C. M. (2017). Comorbid deafblindness and autism spectrum disorder - characteristics, differential diagnosis, and possible interventions. Review Journal of Autism and Developmental Disorders, 4(2), 95-117. https://doi.org/10.1007/s40489-016-0100-2

Rahi, J. S. (2005). Health services experiences of parents of recently diagnosed visually impaired children. British Journal of Ophthalmology, 89(2), 213-218. https://doi.org/10.1136/bjo.2004.051409

Robert, M., Leblanc, L., \& Boyer, T. (2015). When satisfaction is not directly related to the support services received: Understanding parents' varied experiences with specialised services for children with developmental disabilities. British Journal of Learning Disabilities, 43(3), 168-177. https://doi.org/10.1111/bld.12092

Roe, J. (2008). Social inclusion: Meeting the socio-emotional needs of children with vision needs. British Journal of Visual Impairment, 26(2), 147-158. https://doi.org/10.1177/02646196080260020101

Ross, M. C. (2017). Promoting joint attention in children with visual impairment: 
Proposing an intervention using modified strategies from joint attention symbolic play engagement regulation (JASPER) (The Ohio State University). Retrieved from https://etd.ohiolink.edu/!etd.send_file?accession=osu1500289755492111\&dispositio $\mathrm{n}=$ inline

Rowland, C., \& Schweigert, P. (2000). Creating classroom environments that nurture independence for children who are deafblind. Final report. Portland.

Salt, A., \& Sargent, J. (2014). Common visual problems in children with disability. Archives of Disease in Childhood, 99(12), 1163-1168. https://doi.org/10.1136/archdischild-2013-305267

Sandieson, R. (2013). Pearl harvesting comprehensive search filters for searching research literature. Retrieved September 18, 2016, from https://pearlharvestingsearchthesaurus.wikispaces.com/Structure+of+Wiki+Accordi ng+to+PICOS

Sarica, A. D., Akcamete, G., \& Gurgur, H. (2015). A mother-child interaction intervention for mothers of toddlers with visual impairments. International Journal of Early Childhood Special Education, 7(1), 151-169.

Skellenger, A. C., \& Hill, E. W. (1994). Effects of a shared teacher-child play intervention on the play skills of three young children who are blind. Journal of Visual Impairment \& Blindness, 88(5), 433-445.

Solebo, A. L., \& Rahi, J. (2014). Epidemiology, aetiology and management of visual impairment in children. Archives of Disease in Childhood, 99(4), 375-379. https://doi.org/10.1136/archdischild-2012-303002

Stearns, E. M. (2017). Effective collaboration between physical therapists and teachers of students with visual impairments who are working with students with multiple disabilities and visual impairments. Journal of Visual Impairment \& Blindness, 111(2), 166-169. https://doi.org/10.1177/0145482X1711100208

van den Broek, E. G. C., Janssen, C. G. C., van Ramshorst, T., \& Deen, L. (2006). Visual impairments in people with severe and profound multiple disabilities: An inventory of visual functioning. Journal of Intellectual Disability Research, 50(6), 470-475. https://doi.org/10.1111/j.1365-2788.2006.00804.x

van den Broek, E. G. C., van Eijden, A. J. P. M., Overbeek, M. M., Kef, S., Sterkenburg, P. S., \& Schuengel, C. (2017). A systematic review of the literature on parenting of young children with visual impairments and the adaptions for video-feedback intervention to promote positive parenting (VIPP). Journal of Developmental and Physical Disabilities, 29(3), 503-545. https://doi.org/10.1007/s10882-016-9529-6

Webster, A., \& Roe, J. (1998). Children with visual impairments: Social interaction, language and learning. London: Routledge.

Wiley, S., Parnell, L., \& Belhorn, T. (2016). Promoting early identification and intervention for children who are deaf or hard of hearing, children with vision impairment, and children with deafblind conditions. Journal of Early Hearing Detection and Intervention, 1(1), 26-33. https://doi.org/10.15142/T3FW23

World Health Organization. (2012a). Global data on visual impairments 2010. Retrieved February 2, 2016, from http://www.who.int/blindness/GLOBALDATAFINALforweb.pdf

World Health Organization. (2012b, August). Early childhood development and disability. Retrieved from 
https://apps.who.int/iris/bitstream/handle/10665/75355/9789241504065_eng.pdf;jse ssionid=77B839F728DB4AEB370F8590F398C226? sequence $=1$

World Health Organization. (2017). Blindness and visual impairment. Retrieved May 20, 2018, from Blindness and visual impairment website: http://www.who.int/newsroom/fact-sheets/detail/blindness-and-visual-impairment 
Table 1.Characteristics of the included research studies

\begin{tabular}{|c|c|c|c|c|c|c|}
\hline No & Study (Origin) & Sample & Method & Outcomes & Diagnosis & $\begin{array}{l}\text { Quality } \\
\text { appraisal (\%) }\end{array}$ \\
\hline 1 & $\begin{array}{l}\text { (Harley et al., 1986) } \\
\text { USA }\end{array}$ & $\begin{array}{l}\text { Infants } \quad(n=22), \quad \text { parents, } \\
\text { teachers or nurses }\end{array}$ & $\begin{array}{l}\text { Experimental } \\
\text { design }\end{array}$ & $\begin{array}{l}\text { Positive outcomes in cognitive, } \\
\text { movement and touch areas }\end{array}$ & $\begin{array}{l}\text { Visual impairment } \\
\text { and additional } \\
\text { disabilities }\end{array}$ & 75 \\
\hline 2 & $\begin{array}{l}\text { (Erickson et al., } \\
\text { 2007) } \\
\text { USA }\end{array}$ & $\begin{array}{l}\text { Children }(n=3) \text { and their } \\
\text { families, early } \\
\text { interventionists }(n=2)\end{array}$ & Qualitative & $\begin{array}{l}\text { Positive outcomes highlight the } \\
\text { role of early interventionists }\end{array}$ & Visual impairment & 75 \\
\hline 3 & $\begin{array}{l}\text { (Skellenger \& Hill, } \\
\text { 1994) } \\
\text { USA }\end{array}$ & $\begin{array}{l}\text { Children }(n=3) \text {, their } \\
\text { teachers }\end{array}$ & $\begin{array}{l}\text { Multiple probe } \\
\text { technique }\end{array}$ & $\begin{array}{l}\text { Positive outcomes in } \\
\text { increasing play behaviour }\end{array}$ & Visual impairment & 75 \\
\hline 4 & $\begin{array}{l}\text { (Rowland \& } \\
\text { Schweigert, 2000) } \\
\text { USA }\end{array}$ & $\begin{array}{l}\text { Children } \quad(n=12), \text { project } \\
\text { staff }\end{array}$ & Mixed method & $\begin{array}{l}\text { Positive outcomes in } \\
\text { communication and social } \\
\text { interaction skills }\end{array}$ & Deaf-blindness & 25 \\
\hline 5 & $\begin{array}{l}\text { (Joffee, 1988) } \\
\text { USA }\end{array}$ & $\begin{array}{l}\text { Infants }(\mathrm{n}=20) \text { and their } \\
\text { caregivers, occupational } \\
\text { therapist, physical therapist, } \\
\text { early intervention teacher, }\end{array}$ & Qualitative & $\begin{array}{l}\text { Positive outcomes in } \\
\text { foundation needed for the } \\
\text { future development of mobility }\end{array}$ & Visual impairment & 25 \\
\hline 6 & $\begin{array}{l}\text { (Dikowski, 1995) } \\
\text { USA }\end{array}$ & $\begin{array}{l}\text { Children }(\mathrm{n}=50) \text {, and their } \\
\text { parents, teachers, } \\
\text { psychologists and other } \\
\text { professionals }\end{array}$ & Quantitative & $\begin{array}{l}\text { Increased parental knowledge } \\
\text { about visual impairments }\end{array}$ & Visual impairment & 50 \\
\hline 7 & $\begin{array}{l}\text { (Sarica et al., 2015) } \\
\text { Turkey }\end{array}$ & $\begin{array}{l}\text { Children } \quad(n=2), \quad \text { their } \\
\text { caregivers }\end{array}$ & Action research & $\begin{array}{l}\text { Positive outcomes in maternal } \\
\text { interactional behaviours and } \\
\text { children's } \\
\text { behaviours }\end{array}$ & Visual impairment & 75 \\
\hline
\end{tabular}

\section{2 (Continued)}

734 Table 1. Continued 


\begin{tabular}{|c|c|c|c|c|c|c|}
\hline 8 & $\begin{array}{l}\text { (Deborah Chen \& } \\
\text { Haney, 1999) } \\
\text { USA }\end{array}$ & $\begin{array}{l}\text { Infants }(\mathrm{n}=25) \text { and their } \\
\text { caregivers, } \\
\text { interventionists }\end{array}$ & Qualitative & $\begin{array}{l}\text { Increased parental knowledge } \\
\text { about visual impairments and } \\
\text { communicative interaction }\end{array}$ & Deaf-blindness & 75 \\
\hline 9 & $\begin{array}{l}\text { (Janssen et al., 2011) } \\
\text { Netherlands }\end{array}$ & $\begin{array}{l}\text { Child }(n=1) \text {, caregiver and } \\
\text { interaction coach }\end{array}$ & Qualitative & $\begin{array}{l}\text { Positive outcomes in caregiver } \\
\text { behaviour }\end{array}$ & $\begin{array}{lr}\text { Visual impairment } \\
\text { and } & \text { additional } \\
\text { disabilities } & \end{array}$ & 50 \\
\hline 10 & $\begin{array}{l}\text { (Beelmann } \\
\text { Brambring, 1998) } \\
\text { Germany }\end{array}$ & $\begin{array}{l}\text { Children }(\mathrm{n}=10), \quad \text { their } \\
\text { parents, psychologists } \\
(\mathrm{n}=3), \quad \text { special education } \\
\text { teacher }(\mathrm{n}=1)\end{array}$ & Case control & $\begin{array}{l}\text { Positive outcomes in } \\
\text { development, and improved } \\
\text { orientation and mobility } \\
\text { performance }\end{array}$ & Visual impairment & 75 \\
\hline 11 & $\begin{array}{l}\text { (Bregani et al., 1981) } \\
\text { Italy }\end{array}$ & $\begin{array}{l}\text { Children } \quad(n=8), \quad \text { their } \\
\text { parents, interventionists }\end{array}$ & Experimental & $\begin{array}{l}\text { Positive outcomes of parental } \\
\text { training }\end{array}$ & Visual impairment & 50 \\
\hline 12 & $\begin{array}{l}\text { (Bruce, 2002) } \\
\text { USA }\end{array}$ & $\begin{array}{l}\text { Children } \quad(n=3), \text { teachers } \\
(n=2)\end{array}$ & Qualitative & $\begin{array}{l}\text { Positive outcomes regarding } \\
\text { service training }\end{array}$ & Deaf-blindness & 75 \\
\hline 13 & $\begin{array}{l}\text { (Klein, Van Hasselt, } \\
\text { Trefelner, Sandstorm, } \\
\text { \& Brandt-Snyder,1988) } \\
\text { USA }\end{array}$ & $\begin{array}{l}\text { Children }(n=22) \text { and their } \\
\text { caregivers, trainers }\end{array}$ & $\begin{array}{l}\text { Experimental } \\
\text { design }\end{array}$ & $\begin{array}{l}\text { Actual results were not } \\
\text { determined but the } \\
\text { intervention is targeted as } \\
\text { successful }\end{array}$ & $\begin{array}{l}\text { Visual impairment } \\
\text { and additional } \\
\text { disabilities }\end{array}$ & 25 \\
\hline 14 & $\begin{array}{l}\text { (Hill et al., 1995) } \\
\text { Non-determined }\end{array}$ & Child $(n=1)$, observer & $\begin{array}{l}\text { Experimental } \\
\text { design }\end{array}$ & $\begin{array}{l}\text { Partially successful. Positive } \\
\text { outcomes in reaching out and } \\
\text { locating an object }\end{array}$ & $\begin{array}{l}\text { Visual impairment } \\
\text { and additional } \\
\text { disabilities }\end{array}$ & 75 \\
\hline 15 & $\begin{array}{l}\text { (Behl et al., 1993) } \\
\text { USA }\end{array}$ & $\begin{array}{l}\text { Children }(n=35) \text { and their } \\
\text { caregivers }\end{array}$ & $\begin{array}{l}\text { Randomised } \\
\text { control trial }\end{array}$ & $\begin{array}{l}\text { The results highlight the } \\
\text { requirement of more } \\
\text { comprehensive intervention } \\
\text { for infants and toddlers }\end{array}$ & Visual impairment & 50 \\
\hline 16 & $\begin{array}{l}\text { (Dennison, 2001) } \\
\text { USA }\end{array}$ & $\begin{array}{l}1,334 \text { professionals who } \\
\text { made an impact on } 3,455 \\
\text { infants' life }\end{array}$ & Mixed method & $\begin{array}{l}\text { Effectiveness of the project } \\
\text { (in-service training model) is } \\
\text { reported }\end{array}$ & $\begin{array}{l}\text { Visual impairment } \\
\text { with or without } \\
\text { additional disabilities }\end{array}$ & 75 \\
\hline
\end{tabular}

736 (Continued)

Table 1. Continued 


\begin{tabular}{|c|c|c|c|c|c|c|c|}
\hline 17 & $\begin{array}{l}\text { (Dale et al., 2019) } \\
\text { UK }\end{array}$ & $\begin{array}{l}\text { Children }(n=54) \text { and their } \\
\text { parents, practitioners }\end{array}$ & $\begin{array}{l}\text { Longitudinal } \\
\text { observational } \\
\text { study }\end{array}$ & $\begin{array}{lr}\text { No difference } & \text { in } \\
\text { developmental } & \text { setback } \\
\text { Lower parenting stress } & \end{array}$ & $\begin{array}{l}\text { Cortical } \\
\text { impairments }\end{array}$ & visual & 75 \\
\hline 18 & $\begin{array}{l}\text { (Khooshab et al., 2016) } \\
\text { Iran }\end{array}$ & $\begin{array}{l}\text { Mothers }(n=52) \text { with their } \\
\text { children }\end{array}$ & $\begin{array}{l}\text { Randomised } \\
\text { control trial }\end{array}$ & $\begin{array}{l}\text { Intervention group showed } \\
\text { reduced parenting stress }\end{array}$ & Blindness & & 75 \\
\hline
\end{tabular}

Table 2. Search terms

\section{Population}

(Child* OR "early child education*“OR "primary education" OR "Primary class*

OR "Primary school*")

\section{Issue}

("vis* impair*" OR "vision disorder*" OR "vision-impair*" OR "vision

deficiency" OR blind* OR "vision loss" OR "vision problem*" OR "vision

difficult*” OR "impaired vision” OR "partial vision" OR "vision deficiency" OR

"partial sight*” OR "sight loss" OR "low vision")

Table 3. The components of the reviewed interventions 
Orientation and mobility

Collaboration between families and professionals

Professional guidance

Home-based practices

In-service training

Routine-based activities

Family training

Communication practices
Harley et al., 1986; Joffee, 1988

Beelmann \& Brambring, 1998; Behl et al., 1993; Chen \& Haney, 1999; Dale et al., 2019; Dennison, 2001;

Dikowski, 1995; Erickson et al., 2007; Harley et al., 1986; Janssen et al., 2011; Joffee, 1988; Klein et al., 1988; Sarica et al., 2015

Behl et al., 1993; Bregani et al., 1981; Bruce, 2002; Erickson et al., 2007; Harley et al., 1986; Klein et al., 1988

Beelmann \& Brambring, 1998; Behl et al., 1993; Bregani et al., 1981; Chen \& Haney, 1999; Dale et al., 2019;

Dennison, 2001; Harley et al., 1986; Joffee, 1988; Khooshab et al., 2016; Klein et al., 1988; Sarica et al., 2015; Skellenger \& Hill, 1994

Bruce, 2002; Chen \& Haney, 1999; Dennison, 2001; Dikowski, 1995; Harley et al., 1986; Joffee, 1988; Rowland \& Schweigert, 2000; Skellenger \& Hill, 1994

Bruce, 2002; Dikowski, 1995; Rowland \& Schweigert, 2000

Chen \& Haney, 1999; Dale et al., 2019; Harley et al., 1986; Joffee, 1988; Sarica et al., 2015

Bregani et al., 1981; Chen \& Haney, 1999; Janssen et al., 2011; Klein et al., 1988; Rowland \& Schweigert, 2000;

Sarica et al., 2015 
